\title{
Climate Change: Threat to Agricultural System and Food Security in Africa
}

\author{
Victor Adjei* \\ Climate Change and Sustainable Development, University of Ghana, Legon, Ghana
}

\begin{abstract}
Climate change is unequivocal and nothing hides itself from its negative repercussions. Countries in sub-Saharan Africa will continue to be impacted due to their low adaptive capacities and geographic position. Unfavourable weather trends coupled with climatic variations will have adverse effect on agricultural sector which is the main source of livelihood to rural households on the continent. This literature review article assessed the impacts of climate change on agriculture and food security in Africa. The lives of several in Africa cling on agriculture as it supports majority of the population. However, since over 90 percent of agriculture system in the region depends on rainfall, livelihoods of the citizens on the continent have been hit hard due to rising temperature, erratic rainfall and extreme weather conditions.
\end{abstract}

Keywords: Adaptive capacity, Diversification, Climate Variability, Drought

\section{Background}

The impacts of climate change and variability pose a global threat to agricultural growth and human welfare efforts, particularly in sub-Saharan Africa (SSA). The continual decline in agricultural productivity coupled with food price hikes has stern repercussions for food security, especially in third world countries where there is high degree of vulnerability to climate change. ${ }^{1}$ In sub-Saharan Africa, where the majority of the populace survive on climate-sensitive practices, mainly in agricultural production, changing climate and variability poses a developmental challenge..$^{2,3}$

Intergovernmental Panel on Climate Change ${ }^{4}$ upholds climate change occurrence and has projected further change and rise in the characteristics of climate. Nearly all models agree that it will become warmer going forward, however, the extent of such warming is unpredictable. Rainfall on the other hand has been estimated to be highly inconsistent temporally and spatially. ${ }^{4}$ Global Circulation
Models (GCMs) in the African region simulate great uncertainty with regards to the scale of rainfall changes. This is likely to worsen impacts on agriculture that has already triggered instability in production, reduction in crop yield and livestock productivity. This episode would consequently deteriorate hunger among millions of people globally, especially in Africa, Latin America, Small Island and some parts of Asia. This unfortunate upheaval is because of low adaptive capacity attributed to weak resource base, fragile institutions and limited technology. ${ }^{4}$ Projection of the repercussions of climate change and variability on agriculture demonstrates that in future, both production and productivity stability would fall in areas experiencing food insecurity. ${ }^{5}$

Nexus Between Poverty and Hunger in the Face of Climate Change in Africa

Agricultural production in developing countries and most especially among smallholder farmers depending solely on rainfall

\begin{tabular}{|l|l|}
\hline Quick Response Code: & *Corresponding author: Victor Adjei, Climate Change and Sustainable Development, Univer- \\
sity of Ghana, Legon, Ghana
\end{tabular}


has dropped leading to enhanced food insecurity and poverty. ${ }^{6,7}$ With regards to irregular and unpredictable weather patterns, and frequency and intensity of extreme climatic events set to rise due to climate change and variability IPCC, ${ }^{8}$ further reduction in crop yields is anticipated in most of tropical and sub-tropical regions. ${ }^{4}$ This would deteriorate the already existing food insecurity and the prevalence of hunger in developing countries, and undermine the precarious state of smallholder farmers. ${ }^{9}$

In spite of the significant improvement chalked during the previous decades in reducing hunger and its related effects, as of 2015, almost 800 million people were chronically undernourished. Approximately two billion people lack the essential micronutrients they require to enjoy healthy lives globally. ${ }^{10}$ In 2015, according to United Nations, there were still 836 million people in the world living extreme poverty (less than USD1.25/day). International Fund for Agricultural Development (IFAD) argues that at least $70 \%$ of the very poor live in rural areas, most of them depending partly or completely on agricultural for their livelihoods. The more affected are most vulnerable populations and countries, including in semi-arid and arid regions, landlocked countries and small island less endowed countries. ${ }^{11}$

Africa's extremely poor population is estimated to increase for another 30years, peaking at 590 million by 2040 , before decreasing to around 390 by 2063 . These projections exempt those whom may fall into poverty as a result of disasters, rising temperatures and conflict. Nearly all of this population is in sub-Sahara Africa. Populations in Africa that live below the international poverty line have been impacted by growing famine, malnutrition, undernourishment and extreme manifestation of acute food insecurity at an alarming rate. In recent times, factors such as prolonged drought, adverse weather trends, civil unrest, political-economic constraints, diseases (such as HIV/AIDS) as well as poor governance and government policies have resulted in extreme food shortage on the continent. ${ }^{12}$

Poverty in third world countries is predominantly widespread among rural folks as compared to urban settlers. Research has it that agriculture is the principal source of livelihood for the bulk of the populace of these poor rural dwellers. ${ }^{13}$ Smallholder famers also dominate agricultural sector in many countries in sub-Saharan Africa. ${ }^{14}$ Looking at the peasant farmers and their proportional limited scale of production, it is unequivocal that they constitute the majority of the extremely poor. Among farmers even in the agricultural sector, there is some kind of disparity in income and degrees of poverty between farmers who cultivate food crops such as maize and those who farm cash crops such as cocoa or cashew.

According to FAO, ${ }^{5}$ paradoxically, over $70 \%$ of the world's population living in hunger are food producers who are smallholder farmers and sometimes landless farmers. This constraint is wors- ened by their lack of access to markets and inability to influence price systems of their produce. ${ }^{15}$ Their restricted bargaining power characterises their level of output. Some scholars have argued that the only way for such farmers to disentangle themselves is through livelihood diversification. Reardon et al., ${ }^{16}$ Suggest that income and livelihood diversification has been in the living standards of rural small-scale farmers.

Agricultural sector is a vital pivot to eradicate extreme poverty and hunger, and provides livelihood to individuals approximately 1.5 billion globally in smallholder households and vulnerably to climate change and variability, ${ }^{17,18}$ and peasant farmers are disproportionately affected, due to poverty, high dependency on natural resources and insufficient capability to adopt new livelihood strategies. ${ }^{9}$ Study by Rao et al. ${ }^{19}$ states that whereas farmers strive to adapt through innovation, their limited capabilities weaken their response to these swift and irresistible changes beyond their normal experience.

Generally, agriculture is expected to pay a substantial cost of the havoc caused by changing climate. Gradual progress on rural development has already been hit very hard by the combined effects of the worldwide financial recession and food crisis, as a result, malnutrition and hunger patterns remain high. ${ }^{20}$ According to World Development Indicators, ${ }^{21}$ in 2011, approximately 888 million $(12.3 \%)$ of the population in the world were undernourished of which 213 million lived in sub-Saharan Africa. The mortality rate for children under five years of age was incredibly high (about 108), compared to only 51 globally.

\section{Impacts of Changes in Precipitation and Temperature on African Agriculture}

Climate change is projected to continue to compromise agricultural development in Africa. The increasingly unpredictable and irregular natures of weather systems have placed additional burden on rural livelihood and food security on the continent. For instance, widespread destruction of large tracks of farmlands and homes in recent flooding in some places such as Burkina Faso and prolonged drought in Ethiopia and around the Horn of Africa, show clearly the extent of the threat posed by Africa's climate change and variability. ${ }^{20}$ In response to variations in rainfall and atmospheric temperature, Africa is estimated to realise an increase in crop pests and diseases in addition to altered soil fertility. Rising unemployment coupled with declining incomes are expected to hit agriculture sector in combination to deteriorating health. A reduction in nutrient access is likely to augment vulnerability to diseases such as malaria and HIV/AIDS. ${ }^{20}$

According to the 2007 report of IPCC on the projection of impacts of changing climate on African agriculture, it came to light that Africa would be the most vulnerable region to climate change glob- 
ally as a result of multiple stresses of such as poor infrastructure, poverty and governance. The paper further stated that due to temperature rises, crop yields was projected to decline by 50 percent and crop revenue was estimated to fall by as much as 90 percent by $2100 .^{20}$ The changing climate and variability would affect food security on African continent, a region that is already susceptible to food insecurity. ${ }^{4}$ Temperatures would continue to rise making the continent warm especially sub-Saharan region, and it is projected to be greater than the global average. However, precipitation on the other hand will inversely drop in many parts of the continent. For instance, Global Circulation Models (GCMs) have established that atmospheric temperatures are rising throughout the Eastern and Southern African (ESA) regions, whereas precipitation is declining from June through August in southern Africa and ameliorating from December through February in eastern Africa. ${ }^{3}$ Another phenomenon has been reported in the transitional ecological zone of Ghana that the short dry cell separating major season (March-July) and minor season (September-October) is shortening. Also, the same paper reported that there had been late commencement of major season while early cessation of the minor season had been noticed. ${ }^{22,23}$ This had made a lot of food crop producers to shift to the production of cash crop (cashew) which had been identified by the farmers to be somewhat resistant to the erratic rainfall. ${ }^{24}$ Again, in Ghana, climate change is projected to affect crop production, food security, water security, energy supply especially in the northern part of the country. ${ }^{25,26}$

From Figure 1, arid lands cover two-thirds of the African continent and the majority of the region experiences extreme heat during much of the year. This region is characterised by insufficient and scanty precipitation and excessive heat. Intergovernmental Panel on Climate Change has estimated that the Sahel and tropical Western African are 'climate change hotspots'. The two regions are anticipated to experience unparalleled climate around the late 20230 s to 2040 s - earlier than anywhere on the globe. ${ }^{27}$

Figure 1: Climate of Africa.

Source: Welborn, 2018 


\section{Impacts of Climate Change on Agricultural Incomes, Observed and Projected}

Around the globe, negative effects of changing climate are usually noticed more than the positive ones. Various projections have shown that the impacts of climate change and variability on some crops such as wheat and maize in many regions have been impacted negatively. ${ }^{10}$ According to the feedback from major agricultural model inter-comparison projects; there is agreement on the pattern of yield changes in many major agricultural regions in both low and high latitudes. ${ }^{10}$

The agriculture sector, which is the main backbone of countries in sub-Saharan Africa, is likely to experience a prolonged drought and/or floods during the periods of ElNino events. Agriculture losses of between 2-7\% GDP is anticipated by 2100 in several parts of the Sahara, 2-4\% and $0.4-1.3 \%$ in Western and Central Africa and Northern and Southern Africa respectively. ${ }^{20}$ Fisheries will be particularly impacted as a result of changes in sea temperatures that could decline patterns in productivity by $50-60 \%$. According to Overseas Development Institute (ODI), productivity in Africa will be further weakened by a decline in fertile agricultural land available and an expansion in the coverage of low potential land..$^{20}$

Food security in Africa is closely linked to food prices and poverty. Energy prices, climate change and other factors have led to escalation of food prices on the continent since $2008 .^{28}$ For instance, the price of wheat rose by $90 \%$ between June 2010 and March 2011, whereas that of rice increased by 33 percent during the same period. ${ }^{29}$ South Africa is the principal producer and exporter of food on the whole continent. The producer price of wheat had risen by 55 percent between 2008 and 2010 in South Africa. ${ }^{21}$ In Africa, the rise in producer prices is worsened by low agricultural productivity, severe distortions in agriculture markets, vast gaps in infrastructure, a higher incidence of conflict and disproportionate damage from climate change and variability. ${ }^{21}$

Easterling et al. ${ }^{30}$ establishes that climate change will substantially augment the number of persons at risk for hunger compared with the reference scenario of no climate change. Per this climate change scenario, sub-Saharan Africa (SSA) would likely. Asia as the most food-insecure region globally. Increasing food insecurity in Africa will make it extremely harder for the continent to achieve the Millennium Development Goals (MDGs), and higher cost of food, which are likely to characterise reduced agricultural production, will impact already poor population and yields, could have dramatic socio-economic consequences on the. ${ }^{31}$

\section{Conclusion}

Generally, climate change and variability ushers significant constraints to African agricultural development. From food security, nutrition sustainable management, climate change is a substantial threat to the welfare of millions of the rural poor on the African continent.

There are numerous ways through which climate-related factors may affect food security on the region. Such factors may include changes in atmospheric temperature and rainfall patterns, increased frequency and intensity of weather extreme events, acidification and warming of ocean and so forth. Climate change is estimated to impact African continent harder due to its geographic position and other stresses such as poverty. There is the need for leaders on the continent to enhance the resilience and adaptive capacity of their citizens so that they can adjust well as the changing climate has come to stay.

\section{Acknowledgements}

None.

\section{Conflicts of interest}

Author declares that there is no conflict of interest.

\section{Funding}

None.

\section{References}

1. FAO. The state of food and agriculture: climate change, agriculture and food security. Rome. 2016.

2. Thompson HE, Berrang Ford L, Ford JD. Climate change and food security in Sub-Saharan Africa: a systematic literature review. Sustainability. 2010;2(8):2719-2733.

3. Ringler C, Zhu T, Cai X, et al. Climate Change Impacts on Food Security in Sub-Saharan Africa: Insights from Comprehensive Climate Change Modelling. IFPRI Research Brief. Washington, DC: International Food Policy Research Institute. 2010;15-20.

4. IPCC. Climate change 2007: synthesis report. Contribution of Working Groups I, II and III to the Fourth Assessment Report of the Intergovernmental Panel on Climate Change. Core Writing Team, R.K. Pachauri\& A. Reisinger, eds. Geneva, Switzerland, IPCC. 2007. 104 p.

5. FAO. Report of the FAO workshop on climate change and fisheries in the African Great Lakes. Bujumbura. 2010.

6. Boko M, Niang I, Nyong A, e al. Africa. Climate Change 2007. Impacts, Adaptation and Vulnerability: Contribution of Working Group II to the Fourth Assessment Report of the Intergovernmental Panel on Climate Change. In: Parry ML, Canziani OF, Palutikof JP, Van der Linden PJ, Hanson CE, editors. Cambridge, UK: Cambridge University Press. 2007.

7. Mburu B, Muriuki J, Kungu J. Effects of Climate variability and Change on Household Food Sufficiency among Small Scale Farmers of Yatta District, Kenya. Journal of Environment. 2014;3(2):19-27.

8. IPCC. Managing the risks of extreme events and disasters to advance climate change adaptation. In: Field $\mathrm{CB}$, Barros B, Stocker TF, et al, editors. Available from Cambridge University Press, Cambridge, UK. 2012. $582 \mathrm{p}$

9. Osbahr H, Viner D. Linking Climate Change Adaptation and Disaster Risk Management for Sustainable Poverty Reduction. Kenya Country Study. A study carried out for the Vulnerability and Adaptation Resource 
Group (VARG) with support from the European Commission. 2006.

10. FAO. Climate change and food security: risks and responses. Rome: FAO. 2015.

11. FAO. Smallholder Integrated Crop-Livestock Farming Systems: Scoping Study on Climate Smart Agriculture in Kenya. Mitigation of Climate change in Agriculture (MICCA) Programme. Background Report 8.Rome: FAO. 2015.

12. Ngcamu BS, Chari F. Drought Influences on Food Insecurity in Africa: A Systematic Literature Review. International Journal of Environmental Research and Public Health. 2020;17(16):5897.

13. World Bank. Africa's development in a changing climate. 2009.

14. Wiggins S. Can the Smallholder Model Deliver Poverty Reduction and Food Security for a Rapidly Growing Population in Africa? Food and Agricultural Organisation, Rome. 2009.

15. IFAD. Increasing Smallholder Incomes by Supporting Rural Traders. International Fund for Agricultural Development, Rome. 2012.

16. Reardon T. The Rise of Supermarkets in Arica, Asia and Latin America. American Journal of Agricultural Economics. 2003;85(5):1140-1146.

17. Van de Steeg J, Herrero M, Kinyangi J, Thornton P. The Influence of Climate Variability and Climate Change on the Agricultural Sector in East and Central Africa-Sensitizing. The ASARECA Strategic Plan to Climate Change. Report 22. ASARECA (Association for Strengthening Agricultural Research in Eastern and Central Africa), Entebbe, Uganda, and ILRI (International Livestock Research Institute), Nairobi, Kenya. 2009.

18. Schlenker W, Lobell D. Robust Negative Impacts of Climate Change on African Agriculture. Environmental Research Letters. 2010;5(1):1-8.

19. Rao KP, Ndegwa WG, Kizito K, et al. Climate Variability and Change: Farmer Perceptions and Understanding of Intra-Seasonal Variability in Rainfall and Associated Risk in Semi-Arid Kenya. Experimental Agriculture. 2011;47(2):267-291.

20. FAO. Food Security and Agricultural Mitigation in Developing Countries: Options for Capturing Synergies. Rome: FAO. 2009.

21. African Development Indicators (ADI). The World Bank IBRD. Washington, DC: World Bank. 2012.
22. Adjei V, Kyerematen R. Impacts of Changing Climate on Maize Production in the Transitional Zone of Ghana. American Journal of Climate Change. 2018;7:463-476.

23. Adjei V, Kwantwi Boafo L. Maize and Cashew Farming in the Face of Climate Change Variability in the Transitional Zone of Ghana: A Case Study of Nkoranza South Municipality. American Journal of Environmental Sciences. 2019.

24. Adjei V, Anlimachie MA, Ativi EE. Understanding the Nexus between Climate Change, the Shift in Land Use toward Cashew Production and Rural Food Security in Ghana; the Experiences of Farmers in the Transition Zone of Ghana. Journal of Atmospheric Science Research. 2020.

25. Akudugu MA, Dittoh S, Mahama ES. The implications of climate change on food security and rural livelihoods: experiences from Northern Ghana. J Environ Earth Sci. 2012;2(3):21-29.

26. Stanturf JA, Warren ML, Charnley S, et al. Ghana climate change vulnerability and adaptation assessment. United States Agency for International Development, Washington DC. 2011.

27. Isabelle Niang. Africa. In: Christopher B Field, et al., editors. Climate change 2014: impacts, adaptation, and vulnerability. Contribution of Working Group II to the Fifth Assessment Report of the Intergovernmental Panel on Climate Change, IPCC. 2014. 1206.

28. Belloumi M. Investigating the Linkage between Climate Variables and Food Security in ESA Countries. AGRODEP Working Paper 0004. 2014.

29. Salami A, Brixiova Z, Kandil H, et al. Toward Food Security in Africa: Challenges, Policies and the Role of the African Development Bank. Africa Economic Brief. 2011;2(2).

30. Easterling W, Aggarwal P, Batima P, et al. Food Security and Vulnerability. Chapter 5. In: Parry ML, editors. Food, Fiber, and Forest Products. Climate Change 2007: impacts, Adaptation and Vulnerability: Contribution of Working Group II to the Fourth Assessment Report of the Intergovernmental Panel on Climate Change. Cambridge UK: Cambridge University Press. 2007.

31. IFAD. Rural poverty report 2011. New realities, new challenges: new opportunities for tomorrow's generation. 2011. 